\title{
Fra køn til diversitet - intersektionalitet i en dansk/nordisk kontekst
}

\section{Af Ann-Dorte Christensen OG BIRTE SIIM}

Det er nødvendigt med en kritisk refleksion over intersektionalitetsbegrebet og en diskussion af dets anvendelsesmuligheder $i$ en dansk/ nordisk kontekst.

Hvilke spandinger opstår $i$ modet med den oprindelige amerikanske formulering af begrebet og dets serlige udformning $i$ en dansk/ nordisk sammenbang? Og bvilke analytiske forståelser bar formået at analysere det dynamiske samspil mellem strukturer, institutioner og identiteter?

\section{-}


sektionalitetsbegrebet - udviklet med rod i sort amerikansk feminisme - var en mere direkte kritik af racisme og kolonialisme i samfundet og i mainstream feminisme, og denne tilgang har både teoretisk og politisk fået stor gennemslagskraft. Den metodiske kerne er et ikke-additivt princip, der henviser til, at forskellige magthierarkier gensidigt konstruerer hinanden.

As opposed to examine gender, race, class, and nation, as separate systems of oppression, intersectionality explores how these systems mutually construct one another. (Collins 1998, 63)

Det betyder ifølge Nira Yuval-Davis, at ingen af kategorierne giver mening i sig selv.

There is no meaning to the notion of 'black', for instance, which is not gendered or classed, no meaning to the notion of 'women', which is not etnocized and classed etc. (Yuval-Davis 2006, 12)1

Det peger på et behov for at udvikle analysestrategier, der både kan belyse samspillet mellem de forskellige magthierarkier på systemniveau og samtidig fastholde individer og sociale grupper som handlende aktører. $\mathrm{Vi}$ vil vende tilbage til dette spørgsmål, men først se på begrebets udvikling $\mathrm{i}$ forskellige lande. Fx har Baujke Prins (2006) fremhævet forskellen mellem den amerikanske og den engelske intersektionalitetsforståelse, hvor hun skelner mellem en systemisk tilgang (overvejende forankret i USA) og en konstruktivistisk engelsk tilgang, som er mere velegnet til at forstå mangfoldighed og kompleksitet.

Intersektionalitetsbegrebet har de seneste år fået stor gennemslag i nordisk kønsforskning, og diskussionerne herhjemme begynder så småt at sætte deres spor på den internationale debat, hvor Phoenix \& Pattynama har understreget, at begrebsudviklingen også må inddrage den spirende nordiske forskning på området (Phoenix \&
Pattynama 2006 - se også Phoenix’ bidrag i dette nummer af Kvinder, Kon \& Forskning).

Begrebet har ændret karakter på rejsen fra USA - over England - til en dansk/ nordisk kontekst, hvor det var kønsforskere, som beskrftigede sig med postkoloniale studier og med etniske minoritetsgrupper, som først lod sig inspirere af begrebet (de los Reyes, Molina \& Mulinari 2002, Staunæs 2003, Mørck 2003). Der kan her identificeres to hovedpositioner, som repræsenterer henholdsvis et poststrukturalistisk fokus på individers levede liv (Staunæs 2004, Søndergaard 2005) og et postkolonialt fokus på hegemoniske diskurser (Andreassen 2005, de los Reyes \& Mulinari 2005). Der er en spænding mellem de to magtforståelser, og der er behov for at prxcisere analysernes teoretiske præmisser og bagvedliggende magtforståelser. Vi vil argumentere for, at der er behov for at udvikle en tredje position, der har til formål at forbinde sociale strukturer og hegemoniske diskurser med handlende aktører og samtidig er i stand til at kontekstualisere intersektionalitetsbegrebet ud fra en nordisk kønspolitisk model.

Siden kritikken af patriarkatsteorierne har det været afgørende for kønsforskningen at overvinde modsætningen mellem strukturog aktørorienterede tilgange, fx gennem udvikling af mere dynamiske (køns)magtforståelser (Ferguson 1987, Young 1990). Den nordiske kønsforskning har siden 1980'erne været domineret af to konkurrerende magtforståelser, der begge bygger på et begreb om kvinders fælles interesser $i$ at blive inkluderet i samfundet og i politik: Teorien om et "genussystem"2 (Hirdmann 1990, 1996), som betoner den mandlige dominans baseret på kønssegregering og hierarki, og tesen om kvinders empowerment $^{3}$ (Hernes 1987), der betoner magtens produktive sider, dvs. individer og gruppers evne til at handle $\mathrm{i}$ fællesskab for at skabe forandringer. For at overvinde denne splittelse har vi argumenteret for magtforståel- 
ser, der rummer et dobbelt perspektiv, idet de dels henviser til (køns)dominansforhold og dels til magtmobilisering knyttet til individer og gruppers evne til at handle sammen for at skabe forandringer (Christensen \& Siim 1990, Borchorst m.fl. 2003).

Der er et stort behov for at belyse diversitet mellem kvinder og mellem mænd i en nordisk kontekst, og vi ser det som en kreativ udfordring at videreudvikle kønsforskningens magtforståelser ud fra et intersektionalitetsperspektiv: Dels ved at udvide genstandsfeltet fra køn til interaktion mellem køn og andre forskelssættende kategorier med rod i flere og overlappende magt- og ulighedssystemer. Dels metodisk ved at analysere magt på flere samfundsniveauer og -arenaer.

Formålet med artiklen er at bidrage til en (selv)kritisk refleksion af begrebet og diskutere dets anvendelsesmuligheder i en dansk/nordisk kontekst. Vi vil med udgangspunkt i vores egen forskning for det forste diskutere nogle spændinger mellem den oprindelige amerikanske formulering af begrebet og de særlige udformninger, det har fået i en dansk/nordisk sammenhæng. For det andet vil vi præsentere nogle analytiske forståelser, der på eksemplarisk vis har inddraget magtrelationer på forskellige niveauer og dermed har bidraget til at synliggøre og kontekstualisere interaktionen mellem sociale strukturer og det 'levede liv'. Afslutningsvis vil vi argumentere for, at et intersektionalitetsperspektiv lægger op til en kritisk refleksion over kønnets primat i forhold til andre sociale kategorier.

\section{FRA MAGTSTRUKTURER}

\section{TIL DET LEVEDE LIV}

Kimberley Crenshaw (1994) og Patricia Hill Collins' (1998) bidrag har været de centrale inspirationskilder til den danske og nordiske debat. De tager udgangspunkt i sorte kvinders erfaringer med undertrykkelse forankret i magtstrukturer og diskurser om racisme og patriarkat og kritiserer de fe- ministiske og antiracistiske diskurser for at overse henholdsvis race og køn. Problemet er, at farvede kvinder marginaliseres i begge diskurser og at deres multiple undertrykkelse ikke kan tematiseres.

Formålet med Crenshaws analyser er at demonstrere, at kvinders erfaringer med undertrykkelse har rod i samfundets overordnede strukturer. Hun skelner mellem intersektionalitet på flere niveauer: a) strukturel intersektionalitet, dvs. hvordan fx undertrykkelsesformer i forbindelse med vold i hjemmet er forbundet med sorte kvinders position i forhold til klasse og race; b) politisk intersektionalitet, dvs. behovet for at udvikle politiske strategier, som er baseret på sorte kvinders erfaringer med både køn-, klasse- og raceundertrykkelse (Crenshaw 1994 - se også Crenshaw i dette nummer af Kvinder, Kon \& Forskning). Magt er lig med retten til at kategorisere og tillægge kategorier materielle og sociale betydninger: "the way power has clustered around certain categories and is exercised against other" $(1994,112)$.

Med titlen Where have all the subjects gone? Bringing together the concepts of intersectionality and subjectifikation illustrerer Dorthe Staunæs (2003) rammende sit ærinde og det fokus, som hun og andre poststrukturalistiske kønsforskere har i forhold til intersektionalitetsanalyser (se også Kofoed 2005). Ifølge Staunæs er det nødvendigt at gentænke den amerikanske udgave af intersektionalitetsbegrebet med fokus på det levede liv. Formålet er at undersøge, hvordan klassiske baggrundskategorier som køn, etnicitet, race, alder, klasse og seksualitet bliver betydningsbærende og ulighedsskabende i subjektiviseringsprocesser. Staunæs ønsker at bryde med 'lukkede' identitetskategorier og betoner i stedet, at sociale kategorier er noget, man 'gør', ikke noget, man 'er'.

I will suggest bringing to the foreground the doing of intersectionality. This means the doing of the relation between categories, the 
outcome of this doing and how this doing results in either troubled or untroubled subject positions. (Staunæs 2003, 105)

Det empiriske fokus er subjektiveringsprocesser blandt 7. klasse-elever i to forskellige skoler, og undersøgelsen viser overbevisende, hvordan intersektionalitet 'gøres' ikke kun blandt elever fra de etniske minoritetsgrupper, men også blandt elever fra majoritetsgruppen (se også Staunæs 2004).

De postkoloniale teorier er en anden inspirationskilde til udvikling af intersektionalitetsbegrebet med fokus på dekonstruktion af ulighedsskabende diskurser som fx racisme og nationalisme. I bogen Maktens (o)lika förklädnader (de los Reyes, Molina og Mulinari 2002) anvendes intersektionalitet som en teoretisk ramme til analyse af interaktion mellem køn, klasse og etnicitet i det postkoloniale Sverige. Intersektionalitet introduceres som et alternativ til den genusvidenskab, som hidtil har været blind for "den ojämlighet som grundas på föreställningar om "ras", klasstillhörighet og nationale gränser” (Los Reyes \& Mulinari 2005, 7). Rikke Andreassens afhandling Gender, Race, Sexuality Nationality and Sexuality (2005 - se også Andreassens bidrag i dette nummer af Kvinder, Køn \& Forskning) repræsenterer en dansk variant af postkolonialismen med fokus på danske massemediers kommunikation om 'synlige minoriteter'. Afhandlingen viser, hvordan stereotypiseringen af minoriteter bidrager til både at konstruere racisme, sexisme, homofobi og majoritetens selvforståelse som hvide, etniske danskere.

Selvom de forskellige tilgange er inspireret af en Foucaulsk magtforståelse, der betoner magtens diskursive sider (primært $\mathrm{i}$ forhold til kategorisering) og dens produktive sider med mulighed for skabelse af modmagt i forhold til samfundets dominerende magtpositioner, er der også forskelle. Crenshaw er orienteret mod at indkredse strukturelle magtrelationer, mens Staunæs primært ser magten som diskursiv og knyt- tet til konstruktion af identiteter. Endelig er de postkoloniale tilgange optaget af at dekonstruere de hegemoniske og ulighedsskabende diskurser. De tre tilgange har ydet hver deres bidrag til diskussionen af (køns)magtanalyser. I det følgende diskuteres, hvordan intersektionalitetsperspektivet kan videreudvikles i en nordisk kontekst gennem eksempler fra vores egen forskning med vægt på interaktion mellem sociale strukturer og det levede liv. Pointen er, at forskernes valg af analysestrategier ikke kun er knyttet til forskelle i teoretiske positioner, men også til forskelle i kontekst og genstandsfelter.

\section{DE (U)STABILE KATEGORIER PÅ REJSE OVER ATLANTEN}

Da intersektionalitetsbegrebet bevægede sig over Atlanten, skiftede det ikke kun kontekst - det skiftede også genstandsfelt og fik både i England og Danmark en stærkere forankring i den socialkonstruktivistiske kønsforskning. Der er et stort spring fra strukturelle analyser af sorte kvinders undertrykkelse i USA til studier af fx drenges konformitetspres, normalitetsvogtning og 'gørelser' i en dansk skolegård (Kofoed 2005). ${ }^{4}$ Hvor den ene position ønsker at belyse samspillet mellem forskellige undertrykkelses- og dominansformer, er formålet med den anden - poststrukturalistiske - position at indkredse ustabile og betydningsbærende identitetsdannelser.

Et nøglespørgsmål i den forbindelse er, hvorvidt og i hvor høj grad sociale kategorier har en strukturel og institutionel forankring, eller om de primært skal ses som ustabile kategorier, der 'gøres' i det levede liv? Vi ser det som en udfordring at udvikle en tredje position, der kan forbinde de to tilgange. Som med (køns)magtbegrebet vil vi argumentere for et dobbeltperspektiv i intersektionalitetsanalyser, hvor der etableres et samspil mellem de overordnede strukturer (køn, klasse, race) og identitetskonstruktioner i det levede liv. 5 
Et andet centralt spørgsmål er, hvilke analyserammer og -strategier der er egnede til at belyse samspillet mellem de forskellige niveauer, hvor magtrelationerne er virksomme. Vi har tidligere argumenteret for, at magt er et dynamisk og multidimensionalt ${ }^{6}$ begreb, knyttet til forskellige sociale arenaer, fx familie, arbejde og det politiske liv (se Young 1990), og vi har gennem analyser af den danske kønspolitiske model bidraget til at kontekstualisere magtanalyserne $\mathrm{i}$ tid og rum (Christensen \& Siim 2001).

Med udgangspunkt i vores egen forskning vil vi fremhæve to aktuelle problemer, som et intersektionalitetsperspektiv skal bidrage til at overvinde. For det første er det en svaghed, at (køns) magtbegrebet implicit bygger på en præmis om kvinders fælles interesser. Begrebet er ensidigt forankret i et kønsdominansforhold, der fokuserer på mænds strukturelle magt over kvinder, en bestemt kønsarbejdsdeling samt kvinders individuelle og kollektive muligheder for at forandre deres situation (Borchorst m.fl. 2003, 62). Udfordringen er at udvikle en analysestrategi, der integrerer intersektionalitetsperspektivet både begrebsmæssigt og empirisk. Det betyder, at (køns)magten både strukturelt, diskursivt og i forhold til aktørerne ses i et samspil med andre ulighedsskabende kategorier som klasse, etnicitet/ race, generation og seksualitet. For det andet er der et behov for at videreudvikle forståelser af medborgerskab, velfærdsstat og politiske identiteter. Vi har - bl.a. i bogen Kon, modernitet og demokrati - mod nye politiske identiteter (Christensen \& Siim 2001) - opstillet et bud på analyser af kvinders politiske identiteter med udgangspunkt i den danske kønspolitiske model, og vi har understreget, at de aktuelle demokratiske udfordringer ikke 'kun' er knyttet til køn, men også til etnicitet og generation. I en dansk/nordisk kontekst er det stort set lykkedes at inkludere kvinder som aktive medborgere, hvorimod det har vist sig vanskeligt at inkludere etniske minoritetskvin- der i demokratiet. Der er derfor et stort behov for at analysere, hvordan samspillet mellem køn, klasse, etnicitet og generation påvirker det levede liv hos udvalgte grupper (fx unge eller etniske minoriteter) (se Christensen 2003, Siim 2003). Udfordringen er at analysere, hvilken betydning interaktionen mellem ulighedssystemer knyttet til køn, etnicitet og klasse har for det levede liv, samt hvordan kategorierne indgår som et integreret element i den kønspolitiske model, de velfærdsstatslige institutioner og de nationalstatslige rammer.

Tilsvarende har vi i andre studier været med til at argumentere for, at det er vigtigt at kombinere køn og klasse. Fx er der en tendens til, at mænd dominerer både i toppen og bunden af samfundet, hvor vi gennem et begreb om den sociale eksklusions kønsprofil har understreget, at der findes en gruppe mænd, som er særligt udsatte for arbejdsløshed og social eksklusion (Christensen \& Larsen 2003, Larsen 2005, Andersen \& Larsen 2006 - se også Fabers artikel i dette nummer af Kvinder, Kon \& Forskning). Sådanne studier lægger op til at kombinere indsigt i udsatte gruppers hverdagsstrategier med forståelser af, hvordan samspillet mellem køn og klasse er institutionaliseret i den danske velfærds- og arbejdsmarkedsmodel.

Spørgsmålet er, om og hvordan et intersektionalitetsperspektiv kan bidrage til at udvikle en analysestrategi, der er bedre egnet til at indfange diversitet mellem kvinder og mellem mænd, og som samtidig kan belyse, hvordan samspillet mellem køn og andre forskelssættende kategorier indgår som en integreret del af den danske kønspolitiske model.

\section{STRUKTURER, DISKURSER OG SUBJEKTIVITET}

Vi vil i dette afsnit udforske relationen mellem sociale strukturer og det levede liv nærmere med udgangspunkt i to engelske undersøgelser. Den første er Beverly Skeggs’ 
undersøgelse af klasse- og kønsidentiteter blandt unge arbejderkvinder i England. Den anden er Nira Yuval-Davis' analyser af identiteter knyttet til køn, nationalitet og medborgerskab. Formålet er ikke at opstille universelle analysemodeller, men at tydeliggøre samspillet mellem forskellige analyseniveauer og præcisere de konkrete undersøgelsers specifikke kontekst.

Beverley Skeggs 7 bruger ikke direkte intersektionalitetsbegrebet, men som Prins (2006) skriver, har Skeggs i sin forskning demonstreret, hvordan køn- og klasseidentiteter er uløseligt forbundet. Imidlertid arbejder Skeggs (1997, 2004) ikke kun med flere kategorier, hun arbejder også på flere niveauer gennem en interaktion mellem strukturer, diskurser, erfaringer og identiteter. Bogen Formations of Class \& Gen$\operatorname{der}$ (Skeggs 1997) er baseret på et omfattende flerårigt feltarbejde blandt 83 unge engelske arbejderkvinder, der har fulgt såkaldte "caring courses". Det er et af de mindst prestigefyldte kurser, man kan tage i England, og ifølge Skeggs er kvindernes primære begrundelse for at tage kurset da også, at det er bedre end at være arbejdsløs. Skeggs analyserer de unge kvinders skabelse af køns- og klasseidentiteter og deres bestræbelser på at opbygge respektabilitet, som de har vanskeligt ved at kombinere med den negative selvopfattelse, de har af arbejderklassen. Analysen er et overbevisende argument for at arbejde med sociale positioner (forankret i den strukturelle organisering af køn, klasse og race), som sætter rammerne for adgangen til bestemte subjektpositioner (som er præget af anerkendelse/ikke-anerkendelse eller identifikation/dis-identifikation med disse positioner). Med Skeggs' egen rammende formulering:"The young women had a clear knowledge about their 'place' but they were always trying to leave it" (Skeggs 1997, 81).

Når Skeggs kan være så præcis i differentieringen mellem sociale positioner og subjektpositioner, hænger det sammen med, at hun forbinder de to niveauer gennem erfarings- og diskursbegreberne. Efter hendes mening konstrueres subjekter ikke kun gennem diskurser, men også gennem erfaringer. Skeggs $(1997,24)$ lægger dog afstand til standpunktfeminismens tankegang om, at al viden er erfaringsbaseret og at kvinder skulle have særlige erfaringer, der kan danne udgangspunkt for feministiske strategier. I stedet taler hun om kontekstualiserede erfaringer. Det er gennem erfaringer med subjektkonstruktioner "that we come to know and be known" - dvs. erfaringer ses som produktive for handlende subjekter, hvor identiteter aldrig er 'besatte' /occupied eller fixed, men i en kontinuerlig skabelsesproces. Mere konkret betyder $\mathrm{det}$, at kvinder tager aktivt stilling til $\mathrm{fx}$ feminisme i stedet for at blive set som besiddende bestemte identitetspositioner qua køn (eller klasse) (Skeggs 1997, 26-28).

Hvad angår diskursbegrebet, arbejder Skeggs med diskurser på flere niveauer. Således skelner hun mellem: a) brede abstrakte diskurser (fx om respektabilitet og omsorg), som er indlejret $\mathrm{i}$ institutioner i tilknytning til uddannelser eller medier; b) diskurser, som er forankret i bestemte bevægelser (fx feministiske diskurser i tilknytning til kvindebevægelsen eller klassediskurser i tilknytning til arbejderbevægelsen) og c) konkrete og aktuelle diskurser, som ofte er forbundet med konkrete erfaringer ( $\mathrm{fx}$ strejker blandt arbejderne i en mine i lokalområdet eller om kvindefredslejren ved Greenham Common).

Gennem disse forskellige diskursive niveauer får Skeggs konkretiseret og kontekstualiseret ambivalenserne $i$ de unge kvinders køns- og klasseidentiteter. Fx at de på den ene side lægger afstand til arbejderklassen (som fattige, grimme og dumme) og samtidig - på den anden side - føler sig tæt forbundet med $\mathrm{fx}$ de kollektive erfaringer fra minestrejken. Hermed etableres en analytisk ramme, der åbner mulighed for med stor dybde og høj konkretiseringsgrad både at kunne tematisere processer og 
mangfoldighed i identitetsdannelse, men samtidig også fastholde forbindelsen til de overordnede køns- og klassestrukturer, som danner ramme om de unge arbejderkvinders kontekstualiserede erfaringer og de subjektpositioner, som de indtager.

Ann-Dorte Christensens analyser af unge mellemlagskvinders holdninger til feminisme og ligestilling bygger bl.a. på Skeggs' begreber om identifikation og dis-identifikation med feminisme og ligestilling. Analyserne viser, at selvom de unge kvinder er meget orienteret mod ligestilling mellem kønnene, opfatter de 'feminisme' og 'feminist' som stærkt negative identifikationsmarkører. Begreberne forbindes med en bestemt tidsbunden feminisme, der formuleres i skarp kontrast til de unges selvopfattelse og det indhold, som køn, krop og kvindelighed har i deres identitetsdannelse (Christensen 2003, 2006). Et intersektionalitetsperspektiv vil kunne bidrage til ikke kun at synliggøre denne forskel mellem forskellige kvindegenerationer, men også til mere systematisk at indtrenke et klasse- og etnicitetsperspektiv for at bryde med den dominans, som (hvide) mellemlagskvinder har haft $\mathrm{i}$ analyserne både af 1970'er-feminismen og af de unge kvinders holdninger til feminisme og ligestilling i dag.

\section{Nationalitet, MEdborgerskab OG 'BELONGING'}

Nira Yuval-Davis ${ }^{8}$ har anvendt intersektionalitetsbegrebet i forbindelse med sine analyser af medborgerskab, nationale tilhørsforhold og "politics of belonging" (1997, 2006). Hun har bl.a. argumenteret for at medtrnke det nationale og transnationale niveau $\mathrm{i}$ analyser af køn og etnicitet og har understreget behovet for at bryde med identitetspolitikkens hegemoniske diskurser, fordi den usynliggør erfaringer og oplevelser blandt mere marginale medlemmer af bestemte kategorier $(2005,2006)$.

I bogen Gender and Nation (1997) tematiserer Nira Yuval-Davis forholdet mel- lem køn, nation og nationalisme. Et af nøglebegreberne er 'belonging' - både i betydningen af et tilhørsforhold til en familie, et fællesskab og en nation. Nationer er forestillede fællesskaber 'imagined communities', og hovedargumentet er, at menneskers liv - både den hegemoniske majoritet og mindretallene - konstrueres gennem rettigheder og pligter i lokale, etniske, religiøse, nationale, regionale, transnationale og internationale fællesskaber. Yuval-Davis analyserer nationale tilhørsforhold $\mathrm{i}$ forhold til tre dimensioner: a) kvinders bidrag til nationens biologiske reproduktion, som Volknation; b) til nationens kulturelle reproduktion, som Kulturnation; c) til statsborgerskab som Statnation.

Medborgerskab bliver hermed et andet nøglebegreb i Yuval-Davis' intersektionalitetsanalyse. Det er multidimensionelt og dynamisk, idet mennesker samtidig er medlem af flere politiske fællesskaber, og hun analyserer kategorierne køn, klasse og etnicitet i samspil med medlemskab af nationer.

The fact that the citizenship we want to study is that of an Israeli Palestinian is crucial, and radically affects her citizenship in all its tiers. However, other factors, such as her gender, class position, religion, her coming form the city or the village, her ability, her stage in the life cycle and so on - would also all determine her citizenship. (Yuval-Davis 1997, 91)

Da mennesker er medlemmer af mangfoldige fællesskaber, er der behov for at belyse samspillet mellem identiteter, sociale strukturer og konkrete institutioner på flere analyseniveauer.

Yuval-Davis er kritisk over for de dele af intersektionalitetsforskningen som forbliver på ét analyseniveau (ofte erfaringsniveauet) og dermed ikke skelner mellem "social locations, identities and political values" (Yuval-Davis 2006,12-13). Som Skeggs argumenterer hun overbevisende for, at analyser af sociale forskelle må inddrage flere niveauer, idet magtakser på et socialt ma- 
kro-niveau griber ind i menneskers konkrete liv. Ifølge Yuval-Davis antager sociale skillelinjer organisatoriske, intersubjektive, erfaringsmæssige og subjektive former, og det har betydning for den måde, hvorpå vi teoretisk kobler dem (Yuval-Davis 2005, 24).

Yuval-Davis foreslår, at sociale forskelle analyseres på tre niveauer, som alle indeholder både materielle og symbolske betydninger: a) Et institutions- og organisationsniveau - herunder statslige myndigheder og statslig lovgivning, fagforeninger, bistandsorganisationer, familie mv.; b) et relationsniveau - dvs. magt og kærlighedsrelationer mellem faktiske personer både uformelt eller formelt ( $\mathrm{fx}$ interpersonelle relationer $\mathrm{i}$ institutioner); c) et representationsniveau som vedrører billeder, symboler, tekster og ideologier (også de, der indgår i lovgivningen).

Birte Siims (2000 2003) analyser af køn, etnicitet og medborgerskab i et komparativt perspektiv inddrager ligeledes flere analyseniveauer, der omfatter individers rettigheder og pligter i forhold til de politiske institutioner, deres individuelle og kollektive politiske praksis og sammensatte identiteter. Undersøgelsen af en gruppe indvandrerkvinders politiske myndiggørelse belyser de kønnede aspekter af den multikulturelle udfordring til den danske velfærdsstat (Siim 2006). Med udgangspunkt i det levede medborgerskab 9 viser den samspillet mellem politisk aktive kvinders private og offentlige liv og peger på, at indvandrernes religion, familieformer og kultur ikke kun er et problem, men kan være en fordel for kvinders inklusion som lige medborgere. Den illustrerer samtidig politisk aktive kvinders dobbelte følelse af empowerment i det civile samfund og af magtesløshed og mistro over for det politiske system. Et intersektionalitetsperspektiv vil kunne udforske, hvordan ikke blot køn og klasse men også etnicitet indgår som konstituerende elementer i den danske kønspolitiske model og de velfærdsstatslige institutioner. Samti- dig kan et fokus på nationalitet bidrage til at synliggøre det transnationale niveaus betydning for individers rettigheder/pligter, politiske praksis og identiteter.

Sammenfattende mener vi, at de to eksempler på hver sin måde kan bidrage til en kritisk refleksion over styrker og svagheder ved de eksisterende tilgange og positioner i intersektionalitetsforskningen. På trods af forskellige teoretisk/metodiske udgangspunkter peger de begge på, at forholdet mellem sociale kategorier, differentieringer og identiteter må analyseres gennem inddragelse af flere analyseniveauer. Skeggs' tilgang er inspireret af Bourdieus teoretiske forståelse og centrale begreber og lægger vægt på forholdet mellem sociale positioner og subjektpositioner, og Yuval-Davis er inspireret af postkolonialisme og multikulturalisme og lægger mere vægt på den konkrete konteksts betydning for individers handlinger og mangfoldige identiteter. Styrken i deres analysedesign er, at begge medtænker samspillet mellem sociale positioner, de konkrete institutioner og subjektiviteter.

\section{KONKLUSION}

Vi har i artiklen argumenteret for, at der er behov for en kritisk refleksion over centrale præmisser i de eksisterende intersektionalitetspositioner. Vi har peget på, at der eksisterer en række spændinger mellem de forskellige tilgange, specielt mellem sort amerikansk feminisme og dansk/nordisk postkolonialisme og poststrukturalisme, som kan være frugtbare og konstruktive, hvis de ekspliciteres og diskuteres. Budskabet er, at der er et behov for at kontekstualisere intersektionalitetsbegrebet og diskutere, hvilken betydning forskernes udgangspunkter, normative præmisser og teoretisk-metodiske tilgange har for resultaterne.

Hvad er så nyt i intersektionalitetstilgangen $\mathrm{i}$ forhold til andre tilgange? Vi mener ikke, at intersektionalitetsbegrebet kan eller bør udvikles til en ny samlet teoridannelse. 
Vi tolker det snarere som udtryk for et nyt perspektiv, der kan rumme konkurrerende teoretiske og metodiske tilgange og kombineres med kønsteori inspireret af forskellige tilgange og positioner. Vi ser dog også intersektionalitetstilgangen som en stor udfordring for kønsforskningen. For det første, fordi den lægger op til ambitiøse og komplekse analyser, der opererer med flere kategorier og flere analysenivauer. For det andet, fordi intersektionalitetstankegangen uundgåeligt stiller spørgsmålstegn ved en af "kronjuvelerne" i kønsforskningen. Den forudsætter en selvkritisk refleksion over kønnets primat i forhold til andre forskelssættende sociale kategorier og repræsenterer derfor en udfordring til teorier, fx om et genussystem, der på forhånd identificerer køn som den dominerende kategori.

I en dansk og nordisk kontekst er den voksende opmærksomhed på samspillet mellem køn og etnicitet/race vigtig. Danmark og andre lande i Norden har været relativt homogene nationer $i$ forhold til sprog, religion og etnicitet, og der har ikke været en teoretisk eller politisk tradition for at analysere indvandring/ migration, racisme og diskriminering. Der er derfor behov for at diskutere konsekvenserne af forskellige intersektionalitetspositioner og reflektere over styrker og svagheder i de analyserammer, der er udviklet af postkolonialister, poststrukturalister og multikulturalister. Vi har på baggrund af vores egen forskning argumenteret for, at det er en udfordring for et intersektionalitetsperspektiv at medtrnke den særlige danske/nordiske kontekst, specielt den kønspolitiske model, de velfærdsstatslige institutioner og organiseringer i de civile samfund. Disse forhold påvirker samlet set interaktionen mellem klasse, køn og etnicitet på systemniveau, ligesom de spiller sammen med det levede liv og er afgørende for skabelse af individers erfaringer og identiteter.

\section{Noter}

1. Nira Yuval-Davis advarer mod at tage vejkrydsmetaforen for bogstaveligt, da den let kan føre til analyser af selvstændige undertrykkelsesfaktorer (der - ligesom amerikanske motorveje - kommer fra forskellige retninger, mødes og krydser hinanden). Fx er det en udbredt opfattelse, at sorte arbejderkvinder er tre-dobbelt undertrykt i forhold til køn, klasse og race, men herigennem overser man, hvordan de tre forskellige magtrelationer gensidigt konstituerer hinanden.

2. Den svenske historiker Yvonne Hirdmann står som en eksponent for en tilgang, der betoner mænds strukturelle dominans over kvinder, bl.a. i forbindelse med hendes bidrag til den svenske magtudredning og i senere analyser af kvinders position i den svenske velfærdsstat (Hirdmann 1990, 1996). Den norske politolog Helga Maria Hernes (1987) har udviklet tesen om de 'kvindevenlige' skandinaviske velfærdsstater, som bygger på kvinders magtmobilisering, bl.a. gennem velfærdsstatens politikker. Begge forståelser har haft stor teoretisk og politisk gennemslag i Norden.

3. Empowermentbegrebet er bl.a. inspireret af Foucault, men anvendes i mange forskellige tilgange. Se Ferguson (1987) og Young (1990) \& Andersen og Siim (2004).

4. Imidlertid er der også danske/nordiske kønsforskere, som har været orienteret mod at forklare vold og undertrykkelse i forhold til overlappende dominansformer. Det gælder fx Yvonne Mørck, der med udgangspunkt i mordet på svensk-tyrkiske Fadime Sahindal i 2002 argumenterer imod en endimensional forklaring på mordet. Derfor kan spørgsmålet, om Fadime blev dræbt, fordi hun var kvinde eller fordi hun tilhørte en bestemt kultur, ikke besvares, da det netop er i sammenvævningen mellem flere ulighedssystemer og deres forankring i en bestemt (svensk) kontekst, at svaret skal findes (Mørck 2005). Ligeledes har Nina Lykke brugt eksemplet om serbiske soldaters voldtxgt af bosniske kvinder som et eksempel på, at dette skete både pga. af kvindernes køn, etnicitet og nationalitet (Lykke 2003, 48).

5. Den amerikanske sociolog Leslie McCall skelner mellem forskellige intersektionalitetstilgange, og hun er kritisk både over for den poststrukturalistiske metode, hvor kategorier ses som ustabile uden fast forankring, og over for den sorte feminismes fokus på kompleksitet inden for kategorierne køn og race. McCalls pointe er, at kategorierne hverken er fastlåste eller rene sociale fiktioner, og hun argumenterer for en tredje position, hvor de sociale kategorier fungerer som strategiske "anchor- 
points", samtidig med at analysen fastholder åbenhed over for fremkomsten af nye og mere specifikke kategorier i konkrete analyser (McCall 2005). 6. Iris Marion Young har analyseret magtens fem dimensioner: 1) udbytning af arbejde, omsorg og seksuel energi; 2) marginalisering i arbejdslivet; 3 ) magtesløshed og afmagt, $\mathrm{fx}$ i forhold til det politiske system; 4) kulturel imperialisme, fx usynliggørelse og stereotypisering, og 5 ) vold og voldtægt, der støttes af institutioner og social praksis, (se Young 1990, 48-65).

7. Berverly Skeggs er professor i Sociologi ved Goldsmiths University of London, UK.

8. Nira Yuval-Davis er professor i Gender, Sexualities and Ethnic Studies, ved University of East London, UK.

9. "Levet medborgerskab" defineres som 'the meanings that citizenship actually has in peoples lives and the way in which people's social and cultural backgrounds and material circumstances affect their lives as citizens' (Lister 2003, 3).

\section{LITTERATUR}

- Andersen, John \& Jørgen Elm Larsen (2006)

"Det sociale og politiske medborgerskab - køn etnicitet og marginalisering", in Anette Borchorst og Ann-Dorte Christensen (red.): Konsrefleksioner om magt og mangfoldighed. Aalborg Universitetsforlag, pp. 21-40.

- Andersen, John \& Birte Siim (2004) The Politics of Inclusion and Empowerment. Gender, Class and Citizenship. Basingstoke \& New York. Palgrave/ Macmillan.

- Andreassen, Rikke (2005) The Mass Media's Construction of Gender, Race, Sexuality and Nationality. An Analysis of the Danish News Media's Communication about Visible Minorities from 19712004. Department of History, University of Toronto.

- Anthias, Floya \& Nira Yuval-Davis (1983) “Contextualizing Feminism:Gender, Ethnic and Class Divisions", in Feminist Review 1983/15, pp. 6275 .

- Borchorst, Anette, Ann-Dorte Christensen og Birte Siim (2003) "Magtens kønnede ansigter", in Peter Munk Christiansen og Lise Togeby (red.). På sporet af magten. Aarhus Universitetsforlag, pp. 61-73.

. Brah, Avtar \& Ann Phoenix (2004) “Ain’t I A Women? Revisiting Intersectionality", in Journal of International Women's Studies 2004/5 (3), pp. 75-86.

- Christensen, Ann-Dorte (2003) Fortellinger om identitet og magt. Unge kvinder $i$ senmoderniteten. Magtudredningen, Århus.

- Christensen, Ann-Dorte (2006) "Young

Women's Attitudes towards Feminism and Gender Equality", in Christina Carlsson-Wetterberg, Kari Melby, \& Anna-Birte Ravn (eds.): The Limits of Political reform (forthcoming).

- Christensen, Ann-Dorte og Birte Siim (1990)

"Køn, magt og demokrati - mod et dynamisk magtbegreb", in Linda Andersen et al. (red.). Livsmagt. Nye perspektiver på kultur, magt og køn.

Aarhus Universitetsforlag, pp. 7-26.

- Christensen, Ann-Dorte \& Birte Siim (2001) Kon, demokrati og modernitet. Mod nye politiske identiteter. Hans Reitzels Forlag, København. - Christensen, Ann-Dorte og Jørgen Elm Larsen (2003) "Mænds ligestilling - om behovet for en differentieret ligestillingsforståelse", i Anette Borchorst og Drude Dahlerup Ligestillingspolitik som diskurs og praksis. Samfundslitteratur, København, pp. 125-144.

. Collins, Patricia Hill (1998) "It's all in the family: Intersections of gender, race and nation", in Hypatia 1998/3, vol. 13, pp. 62-82.

- Crenshaw, Kimberle W. (1994) "Mapping the Margins - Intersectionality, Identity Politics and Violence Against Women of Colour", in Martha Finneman \& Mykitiuk, Rixanne (eds.): The Public Nature of Private Violence. The Discocery of Domestic Abuse. Routledge, London, pp. 93-118.

- de los Reyes, Pauline og Diana Mulinari (2005)

Intersektionalitet. Kritiska refleksioner över (o)jämliktetens landskap. Liber, Lund.

- Ferguson, Kathy (1987) "Male-Ordered Politics: Feminism and Political Science", in Terense Ball (ed.) Idioms of Inquiry - Critique and Renewal in Political Science. New York University Press, Albany, pp. 209-229.

- Hernes, Helga Maria (1987) Welfare State and Women Power. Oslo, Norwegian University Press. . Hirdmann, Yvonne (1990) "Genussystemet", in Demokrati och Makt i Sperige. Maktudredningens huvudrapport, Stockholm: SOU: 44, pp. 73-116. - Hirdmann, Yvonne (1996) Key Concepts in Feminist Theory. Analyzing Gender and Welfare.

FREIAs tekstserie nr. 34, Aalborg Universitet.

- Hooks, Bell (1981) Ain't I a Woman. South End Press, Boston, MA.

- Kofoed, Jette (2005) "Holddeling: Når der gøres maskulinitet og hvidhed", in Kvinder, køn o Forskning 2003/3, pp. 42- 52.

- Larsen, Jørgen Elm (2005) Fattigdom og social eksklusion. Tendenser i Danmark over et kvart århundrede. Socialforskningsinstituttet, København. 
- Lister, Ruth (2003) Citizenship. Feminist Perspectives. 2nd ed. Palgrave, Basingstoke \& New York. . Lykke, Nina (2003: "Intersektionalitet - ett användbart begrepp för genusforskningen", Kvinnovetenskaplig Tidsskrift 2003/1, pp. 47-55.

- Mørck, Yvonne (2003) "Narratives of the intersections of masculinities and ethnicities in a Danish high school class", in NORA 2003, vol. 11/2, pp. 111-120.

- Mørck, Yvonne (2005) "Intersektionalitetsanalyser og diversitetsudfordringer", in Henning Bech og Anne Scott Sørensen (red.): Kultur på kryds og tvars. Forlaget Klim, Århus, pp. 65-87. - McCall, Leslie (2005) "The Complexity of Intersectionality", in Signs. Journal of Women in Culture and Society 2005, vol. 30/3, pp.1771-1800. - Prins, Baujke (2006) "Narrative Accounts of Origins. A Blind Spot in the Intersectional Approach?", in European Journal of Women's Studies, 2006, vol. 13/3, pp. 277-290.

- Phoenix, Ann \& Pamela Pattynama (2006) "Intersectionality", European Journal of Womens's Studies 13/3, pp. 187-192.

- Siim, Birte (2000) Gender and Citizenship. Politics and Agency in France, Britain and Denmark. Cambridge University Press, Cambridge.

- Siim, Birte (2003: Medborgerskabets udfordringer - etniske minoritetskvinders politiske myndiggorelse. Magtudredningen, Århus.

- Siim, Birte (2006) "Dilemmas of citizenship tensions between gender equality and respect for diversity in the Danish welfare state" in Christina Carlsson-Wetterberg, Kari Melby, \& Anna-Birte Ravn (eds.): The Limits of Political reform (forthcoming).

- Skeggs, Beverly (1997) Formations of Class and Gender. Sage Publications, London.

- Skeggs, Berverly (2004) Class, Self, Culture.

Routledge, London and New York.

- Staunæs, Dorthe (2004) Kon, etnicitet og skoleliv. Samfundslitteratur, Frederiksberg.

. Staunæs, Dorthe (2003) "Where have all the subjects gone? Bringing together the concepts of intersectionality and subjectification", in NORA 2003, vol. 11/2, pp. 101-110.

- Søndergaard, Dorte Marie (2005) "Making Sense of Gender, Age, Power and Disciplinary Position: Intersecting Discourses in the Academy", in Feminism \& Psychology 2005, 15/2.

- Williams, Fiona (1995) "Race/Ethnicity, Gender and Class in Welfare States: A Framework for Comparative Analysis", in Social Politics 1995, vol. 2 , no. 2 , pp.127-158.
- Young, Iris (1990) Justice and the Political Difference. Oxford University Press, Oxford.

- Yuval-Davis (1997) Gender and Nation. Sage

Publications, London.

- Yuval-Davis, Nira (2006) "Intersectionality, Citizenship and Contemporary Politics of Belonging", forthc. i CRISPP, Critical Revue of International, Social and Political Philosophy, Special Issue "Contesting Citizenship" 2006, vol. 9/4.

. Yuval-Davis, Nira (2005) "Gender mainstreaming och intersektionalitet", in Kvinnovetenskapelig tidsskift 2005, vol. 26/2-3, pp.19-29.

\section{SUMMARY}

Intersectionality is a travelling concept rooted in Black Feminism that has recently been adopted by Nordic gender research. The concept has been transformed on its way from the US to the Danish/Nordic context. The purpose with this article is to contribute to a critical reflection of the concept and discuss its potentials from a Danish/Nordic context. Adopting a social science optic we first discuss some tensions between the original American understanding of the concept and the special - predominantly poststructural and postcolonial conceptualisation given in the Danish/ Nordic context. Secondly we present two analytical frames able to analyse the dynamic interaction between different forms of power and between structures, institutions and identities. We argue that intersectionality is not a coherent theory but a new perspective able to contain different and competing theoretical and methodological approaches.

Ann-Dorte Christensen, ph.d, lektor, Institut for Historie, Internationale Studier og Samfundsforhold, Aalborg Universitet

Birte Siim, professor, Institut for Historie, Internationale Studier og Samfundsforhold, Aalborg Universitet 